\title{
Protocol
}

\section{Isolation of Ribosomes and Polysomes}

\author{
Maria C. Rivera, ${ }^{1,4}$ Bruce Maguire, $^{2}$ and James A. Lake ${ }^{3}$ \\ ${ }^{1}$ Department of Biology and Center for the Study of Biological Complexity, Virginia Commonwealth University, \\ Richmond, Virginia 23284; ${ }^{2}$ Primary Pharmacology Group, Pfizer Global Research and Development, Groton, \\ Connecticut 06340; ${ }^{3}$ Department of Molecular, Cell and Developmental Biology and Department of Human \\ Genetics, University of California, Los Angeles, California 90095
}

\begin{abstract}
Here we describe a preparative differential centrifugation protocol for the isolation of ribosomes from a crude cell homogenate. The subcellular fraction obtained is enriched in ribosome monomers and polysomes. The protocol has been optimized for the homogenization and collection of the ribosomal fraction from prokaryotic cells, mammalian and plant tissues, reticulocytes, and chloroplasts. The quality of the ribosomal preparation is enhanced by the removal of the remaining cellular components and adsorbed proteins by pelleting through a sucrose cushion with a high concentration of monovalent salts, $\mathrm{NH}_{4} \mathrm{Cl}$ or $\mathrm{KCl}$. The different components of the ribosomal fraction isolated using this protocol can be further purified by sucrose gradient centrifugation.
\end{abstract}

MATERIALS

It is essential that you consult the appropriate Material Safety Data Sheets and your institution's Environmental Health and Safety Office for proper handling of equipment and hazardous materials used in this protocol.

RECIPES: Please see the end of this protocol for recipes indicated by $<R>$. Additional recipes can be found online at http://cshprotocols.cshlp.org/site/recipes.

Reagents

Cell culture (with appropriate growth medium) or tissue (mammalian or plant) of interest

One of the most critical factors for optimal ribosome purification is the quality of the cells from which the ribosomes are to be isolated. The best material is usually obtained from cells growing rapidly in a rich medium at their optimal temperature and harvested in early to mid-log phase long before growth and translation start to slow. For E. coli, strains lacking RNase I, such as MRE600, A19, and Q13, are preferred.

Chloramphenicol or cycloheximide (optional; see Step 1)

Chloroplast lysis buffer $<\mathrm{R}>$

DNase (RNase-free)

Dry ice/ethanol bath (optional; see Step 1)

Homogenization buffer appropriate for preparation of interest (see Step 3)

Chloroplast homogenization buffer $<\mathrm{R}>$

French press buffer for prokaryotic $70 \mathrm{~S}$ ribosomes $<\mathrm{R}>$

French press buffer for prokaryotic polysomes $<\mathrm{R}>$

Mammalian ribosome homogenization buffer $<\mathrm{R}>$

\footnotetext{
${ }^{4}$ Correspondence: mcrivera@vcu.edu

(C) 2015 Cold Spring Harbor Laboratory Press

Cite this protocol as Cold Spring Harb Protoc; doi:10.1101/pdb.prot081331
} 
M.C. Rivera et al.

\section{Equipment}

Centrifuge (Sorvall), SS-34 rotor (Sorvall), and tubes

DEPC-treated cheesecloth

Pretreat cloth by soaking in $0.1 \%$ DEPC for $12 \mathrm{~h}$ and then autoclave.

Instrument appropriate to disrupt cells of interest (see Step 3)

Blender

French press

Glass homogenizer with a motor-driven or hand-held loose-fitting Teflon pestle

Mortar and pestle

Ultracentrifuge (Beckman), Type 50.2 Ti rotor (Beckman), and tubes

Always follow the manufacturer's recommendations and safety information for operating the ultracentrifuge and filling ultracentrifuge tubes.

\section{Preparation of Cell Extracts}

If harvesting ribosomes from cultured cells, start at Step 1. If using mammalian or plant tissue, start at Step 3. Carry out all steps after cell harvesting on ice or at $4^{\circ} \mathrm{C}$. Use sterile and/or RNase-free disposable plasticware where possible.

1. Culture desired cell type in appropriate medium. Harvest by centrifugation.

Generally, a 4-L culture of E. coli yields $\sim 7.5 \mathrm{~g}$ of cell paste. The cell paste may be frozen in a dry ice/ethanol bath immediately after harvesting and stored at $-80^{\circ} \mathrm{C}$.

If high yields of polysomes are desired, preserve the polysomes by chilling the culture rapidly and adding $100 \mu \mathrm{g} / \mathrm{mL}$ of chloramphenicol (for prokaryotes) or $100 \mu \mathrm{g} / \mathrm{mL}$ of cycloheximide (for eukaryotes) just before harvest.

2. Resuspend 5-10 g of fresh or frozen cell paste from Step 1 in the appropriate homogenization buffer (see Step 3) at a 1:2 (w:v) ratio. Add RNase-free DNase to a final concentration of $2 \mu \mathrm{g} / \mathrm{mL}$ and set aside for $20 \mathrm{~min}$ at $4^{\circ} \mathrm{C}$.

Vanadyl ribonucleoside complex can be added to any buffer at a concentration of 10 mм to inhibit RNases. If doing so, omit EDTA from the homogenization buffer.

3. Disrupt the cells as follows.

\section{For Prokaryotic Ribosomes}

i. Disrupt cells in a prechilled French press at 16,000 pounds per square inch (psi) in French press buffer for prokaryotic $70 \mathrm{~S}$ ribosomes. 
Follow the manufacturer's instructions for safe and proper operation of the French press. Generally, once the predetermined pressure reading is reached, while maintaining the psi, open the flow valve to allow the liquid to flow from the sample outlet. Adjust the flow rate to $\sim 15$ drops per minute. Collect the lysate in a flask kept on ice.

\section{For Prokaryotic Polysomes}

ii. Disrupt cells in a prechilled French press at 13,800 psi in French press buffer for prokaryotic polysomes.

Follow the manufacturer's instructions for the French press (see Step 3.i).

\section{For Mammalian Tissue Ribosomes and Polysomes}

iii. Mince the tissue and resuspend in 2 volumes of mammalian ribosome homogenization buffer. Homogenize the suspension in a glass homogenizer using eight to 10 strokes with a motor-driven loose-fitting Teflon pestle.

Determine the amount of starting material empirically and based on availability. This disruption is optimized for tissue such as liver. If another type of tissue or cultured cells will be used, it is important to optimize the homogenization conditions including the buffer; in most cases a detergent lysis may be required.

\section{For Mammalian Reticulocyte Ribosomes}

iv. Resuspend cells in 2 volumes of reticulocyte homogenization buffer. Homogenize the suspension with three strokes using a glass homogenizer and a hand-held loose-fitting Teflon pestle.

\section{For Plant Cytoplasmic Ribosomes and Polysomes}

v. Wash 25-100 g of plant tissue in RNase-free $\mathrm{H}_{2} \mathrm{O}$ at room temperature.

vi. Freeze tissue in liquid nitrogen and macerate to a fine powder using a cold mortar and pestle.

vii. Resuspend the powder in 2 volumes of cold plant extraction buffer. Homogenize the suspension in a blender by applying 15 -sec pulses at 1-min intervals. Do this four times.

viii. Pass the homogenate through two layers, and then eight layers, of cold DEPC-treated cheesecloth.

\section{For Chloroplast Ribosomes}

ix. Wash $250 \mathrm{~g}$ of plant leaves in RNase-free $\mathrm{H}_{2} \mathrm{O}$.

x. Suspend the leaves in $250 \mathrm{~mL}$ of cold chloroplast homogenization buffer. Homogenize the suspension in a blender for $45 \mathrm{sec}$.

xi. Filter the suspension through a cold DEPC-treated cheesecloth.

xii. Clarify the extract by centrifuging at $360 \mathrm{~g}$ for $5 \mathrm{~min}$ at $4^{\circ} \mathrm{C}$. Discard the pellet.

xiii. Pellet the chloroplasts by centrifugation at $1200 \mathrm{~g}$ for $15 \mathrm{~min}$ at $4^{\circ} \mathrm{C}$.

xiv. Wash the pellet with chloroplast homogenization buffer and repellet the chloroplasts by centrifugation at $1200 \mathrm{~g}$ for $15 \mathrm{~min}$ at $4^{\circ} \mathrm{C}$.

$\mathrm{xv}$. Disrupt the membranes and lyse the chloroplasts by resuspending the chloroplast pellet in $50 \mathrm{~mL}$ of chloroplast lysis buffer containing either sodium deoxycholate $(0.5 \%$ final concentration) or Triton X-100 (1.0\% final concentration).

4. Clear the lysate of cell debris by centrifugation at $4^{\circ} \mathrm{C}$ using an SS-34 rotor at the following speeds and times.

\section{For Prokaryotic Ribosomes}

i. Centrifuge at $30,000 \mathrm{~g}(15,800 \mathrm{rpm})$ for $30 \mathrm{~min}$. Save the supernatant and proceed to Step 5. 
M.C. Rivera et al.

\section{For Prokaryotic Polysomes}

ii. Centrifuge at $7700 \mathrm{~g}(8000 \mathrm{rpm})$ for $8 \mathrm{~min}$. Save the supernatant and proceed to Protocol: Purification of Polysomes (Rivera et al. 2014b).

\section{For Mammalian Tissue Ribosomes and Polysomes}

iii. Centrifuge at 20,000 $\mathrm{g}(12,900 \mathrm{rpm})$ for $10 \mathrm{~min}$. Save the supernatant and proceed to Step 5 .

\section{For Mammalian Reticulocyte Ribosomes}

iv. Centrifuge at 20,000 $\mathrm{g}(12,900 \mathrm{rpm})$ for $10 \mathrm{~min}$. Save the supernatant and proceed to Step 5 .

\section{For Plant Cytoplasmic Ribosomes and Polysomes}

v. Centrifuge at $1076 \mathrm{~g}(3000 \mathrm{rpm})$ for $7 \mathrm{~min}$.

vi. Add 0.1 volume of $20 \%$ Triton X-100 to the supernatant and centrifuge at 17,210g (12,000 $\mathrm{rpm}$ ) for $20 \mathrm{~min}$. Save the supernatant and proceed to Step 5.

\section{For Chloroplast Ribosomes}

vii. Centrifuge at $26,000 \mathrm{~g}(14,700 \mathrm{rpm})$ for $20 \mathrm{~min}$. Save the supernatant and proceed to Step 5.

Isolation of Ribosomes and Polysomes

5. Gently layer the crude lysate from Step 4 at a 1:1 (v:v) ratio over the appropriate sucrose cushion (see below) using a pipette. Take care to do this slowly so that a sharp interface is obtained between the cushion and the less-dense layer above. Then centrifuge at $4^{\circ} \mathrm{C}$ in the Beckman fixedangle Type $50.2 \mathrm{Ti}$ rotor per the guidelines below.

\section{For Prokaryotic Ribosomes}

i. Pellet the 70 S ribosomes by centrifugation at $100,000 \mathrm{~g}(28,800 \mathrm{rpm})$ for $16 \mathrm{~h}$ over the highsalt sucrose cushion buffer for prokaryotic ribosomes.

This step involves long centrifugation times to bring down 70S ribosomes as well as dissociated 30S and $50 S$ ribosomal subunits. Minimal centrifugation conditions can be used to primarily pellet 705 rather than 505 or 305 subunits.

ii. If necessary, repeat two or three times until a clean pellet is obtained.

For methanogens, halobacteria, and eocytes (sulfur-metabolizing hyperthermophiles), at least two high-salt washes are necessary to adequately remove the nonribosomal debris.

iii. Use, store (at $-80^{\circ} \mathrm{C}$ ), or further purify the ribosome-containing pellet as desired.

For further purification of the $70 S$ ribosomes, proceed to Protocol: Purification of 705 Ribosomes (Rivera et al. 2014a).

\section{For Mammalian Ribosomes and Polysomes}

iv. Centrifuge at $100,000 \mathrm{~g}(28,800 \mathrm{rpm})$ for $24 \mathrm{~h}$ over the mammalian sucrose cushion buffer.

v. Use the pellet containing polysomes and monosomes or store at $-80^{\circ} \mathrm{C}$.

\section{For Plant Cytoplasmic Ribosomes and Polysomes}

vi. Centrifuge at 150,000 $\mathrm{g}(35,300 \mathrm{rpm})$ for $3 \mathrm{~h}$ over the plant sucrose cushion buffer.

vii. Carefully wash or rinse the pellet with resuspension buffer for plant ribosomes and then resuspend in $200 \mu \mathrm{L}$ of resuspension buffer for plant ribosomes.

The pellet suspension contains mainly polysomes and ribosome monomers. The plant polyribosomal fraction contains two types of ribosomes, cytoplasmic (80S) and chloroplast (70S). To include the free ribosomal subunits, increase the centrifugation time to at least $16 \mathrm{~h}$. 
viii. Use, store (at $-80^{\circ} \mathrm{C}$ ), or further purify the resuspended pellet as desired.

For further purification of the polysomes, proceed to Protocol: Purification of Polysomes (Rivera et al. 2014b).

\section{For Chloroplast Ribosomes}

ix. Centrifuge at 55,000g (21,400 rpm) for $12 \mathrm{~h}$ over the high-salt sucrose cushion buffer for chloroplast ribosomes.

$\mathrm{x}$. Remove the sucrose by rinsing the pellet in high-salt sucrose cushion buffer without sucrose, $1: 1$ (v:v) ratio, and quickly spin the resuspension at 10,000 $\left(9100 \mathrm{rpm}\right.$ ) for $10 \mathrm{~min}$ at $4^{\circ} \mathrm{C}$.

$\mathrm{xi}$. Use the ribosome-containing pellet or store at $-80^{\circ} \mathrm{C}$.

\section{RECIPES}

\section{Chloroplast Homogenization Buffer}

$100 \mathrm{~mm}$ Tris- $\mathrm{HCl}(\mathrm{pH} 7.5)$

5 mм MgOAc

$50 \mathrm{~mm} \mathrm{KCl}$

5 mм $\beta$-mercaptoethanol

0.7 м sucrose (certified RNase-free)

Prepare in ultrapure (MilliQ) or certified RNase-free water. Filter-sterilize through a $0.22-\mu \mathrm{m}$ filter.

\section{Chloroplast Lysis Buffer}

$100 \mathrm{~mm}$ Tris- $\mathrm{HCl}(\mathrm{pH} 7.5)$

$10 \mathrm{~mm} \mathrm{MgOAc}$

$50 \mathrm{mM} \mathrm{NH}_{4} \mathrm{Cl}$

6 mм $\beta$-mercaptoethanol

Prepare in ultrapure (MilliQ) or certified RNase-free water. Filter-sterilize through a $0.22-\mu \mathrm{m}$ filter.

French Press Buffer for Prokaryotic 70S Ribosomes

20 mм Tris- $\mathrm{HCl}(\mathrm{pH} 7.5)$

$50 \mathrm{~mm} \mathrm{MgOAc}$

$100 \mathrm{mM} \mathrm{NH}_{4} \mathrm{Cl}$

$1.0 \mathrm{~mm}$ DTT

0.5 mM EDTA

Prepare in ultrapure (MilliQ) or certified RNase-free water. Filter-sterilize through a $0.22-\mu \mathrm{m}$ filter.

French Press Buffer for Prokaryotic Polysomes

$20 \mathrm{~mm}$ Tris- $\mathrm{HCl}$ (pH 7.6)

$50 \mathrm{~mm} \mathrm{MgCl}_{2}$ $150 \mathrm{mM} \mathrm{NH}_{4} \mathrm{Cl}$

Prepare in ultrapure (MilliQ) or certified RNase-free water. Filter-sterilize through a $0.22-\mu \mathrm{m}$ filter. 
M.C. Rivera et al.

High-Salt Sucrose Cushion Buffer for Chloroplast Ribosomes

$10 \mathrm{~mm}$ Tris- $\mathrm{HCl}(\mathrm{pH} 7.5)$

$10 \mathrm{~mm} \mathrm{MgOAc}$

$150 \mathrm{~mm} \mathrm{KCl}$

$6 \mathrm{~mm} \beta$-mercaptoethanol

1 м sucrose (certified RNase-free)

Prepare in ultrapure (MilliQ) or certified RNase-free water. Filter-sterilize through a $0.22-\mu \mathrm{m}$ filter.

High-Salt Sucrose Cushion Buffer for Prokaryotic Ribosomes

$20 \mathrm{~mm}$ Tris- $\mathrm{HCl}(\mathrm{pH} 7.5)$

$50 \mathrm{~mm} \mathrm{MgOAc}$

$100 \mathrm{mM} \mathrm{NH}_{4} \mathrm{Cl}$

$1 \mathrm{~mm}$ DTT

$0.5 \mathrm{~mm}$ EDTA

1.1 M sucrose (certified RNase-free)

Prepare in ultrapure (MilliQ) or certified RNase-free water. Filter-sterilize through a $0.22-\mu \mathrm{m}$ filter.

\section{Mammalian Ribosome Homogenization Buffer}

$50 \mathrm{~mm}$ Tris- $\mathrm{HCl}(\mathrm{pH} 7.5)$

$5 \mathrm{mM} \mathrm{MgCl}_{2}$

$25 \mathrm{~mm} \mathrm{KCl}$

0.2 M sucrose (certified RNase-free)

Prepare in ultrapure (MilliQ) or certified RNase-free water. Filter-sterilize through a $0.22-\mu \mathrm{m}$ filter.

Mammalian Sucrose Cushion Buffer

$50 \mathrm{~mm}$ Tris- $\mathrm{HCl}(\mathrm{pH} 7.5)$

$5 \mathrm{mM} \mathrm{MgCl}_{2}$

$25 \mathrm{~mm} \mathrm{KCl}$

2 м sucrose (certified RNase-free)

Prepare in ultrapure (MilliQ) or certified RNase-free water. Filter-sterilize through a $0.22-\mu \mathrm{m}$ filter.

Plant Extraction Buffer

$50 \mathrm{~mm}$ Tris- $\mathrm{HCl}$ (pH 9.0)

$30 \mathrm{mM} \mathrm{MgCl}_{2}$

$400 \mathrm{~mm} \mathrm{KCl}$

17\% (w/w) sucrose (certified RNase-free)

Prepare in ultrapure (MilliQ) or certified RNase-free water. Filter-sterilize through a $0.22-\mu \mathrm{m}$ filter.

\section{Plant Sucrose Cushion Buffer}

$20 \mathrm{~mm}$ Tris- $\mathrm{HCl}(\mathrm{pH} 7.6)$

$5 \mathrm{~mm} \mathrm{MgCl}_{2}$

$50-200 \mathrm{mM} \mathrm{NH}_{4} \mathrm{Cl}$

$60 \%(w / w)$ sucrose (certified RNase-free)

Prepare in ultrapure (MilliQ) or certified RNase-free water. Filter-sterilize through a $0.22-\mu \mathrm{m}$ filter. 
Resuspension Buffer for Plant Ribosomes

$50 \mathrm{~mm} \mathrm{KCl}$

$20 \mathrm{~mm}$ Tris- $\mathrm{HCl}(\mathrm{pH} 7.6)$

$5 \mathrm{~mm} \mathrm{MgCl}_{2}$

Prepare in ultrapure (MilliQ) or certified RNase-free water. Filter-sterilize through a $0.22-\mu \mathrm{m}$ filter.

Reticulocyte Homogenization Buffer

$10 \mathrm{~mm}$ Tris- $\mathrm{HCl}(\mathrm{pH} 7.5)$

$1.5 \mathrm{~mm} \mathrm{MgCl}_{2}$

$10 \mathrm{~mm} \mathrm{KCl}$

$2 \mathrm{~mm}$ DTT

Prepare in ultrapure (MilliQ) or certified RNase-free water. Filter-sterilize through a $0.22-\mu \mathrm{m}$ filter.

\section{REFERENCES}

Rivera MC, Maguire BA, Lake JA. 2014a. Purification of 70S ribosomes. Cold Spring Harb Protoc doi: 10.1101/pdb.prot081356.
Rivera MC, Maguire BA, Lake JA. 2014b. Purification of polysomes. Cold Spring Harb Protoc doi: 10.1101/pdb.prot081364. 


\title{
Isolation of Ribosomes and Polysomes
}

\author{
Maria C. Rivera, Bruce Maguire and James A. Lake
}

Cold Spring Harb Protoc; doi: 10.1101/pdb.prot081331

\begin{tabular}{cc}
$\begin{array}{r}\text { Email Alerting } \\
\text { Service }\end{array}$ & Receive free email alerts when new articles cite this article - click here. \\
\hline $\begin{array}{c}\text { Subject } \\
\text { Categories }\end{array}$ & $\begin{array}{c}\text { Browse articles on similar topics from Cold Spring Harbor Protocols. } \\
\text { Cell Biology, general (1382 articles) } \\
\text { Subcellular Fractionation (88 articles) }\end{array}$ \\
\hline
\end{tabular}

